\title{
Consensus for the diagnosis, prognosis and treatment of feline mammary tumors
}

\section{Consenso para o diagnóstico, prognóstico e tratamento de tumores mamários em felinos}

\section{Geovanni Dantas CASSALI'; Cecília Bonolo de CAMPOS²; Angélica Cavalheiro BERTAGNOLLI³;}

Alessandra ESTRELA-LIMA ${ }^{4}$; Gleidice Eunice LAVALLE ${ }^{5}$ Karine Araújo DAMASCENO ${ }^{6}$;

Andrigo Barboza DE NARDI ${ }^{7}$; Bruno COGLIATI ${ }^{8}$; Fernanda Vieira Amorim da COSTA ${ }^{9}$; Renata SOBRAL ${ }^{10}$; Giovana Wingeter DI SANTIS ${ }^{11}$; Cristina Gevehr FERNANDES ${ }^{12}$; Enio FERREIRA ${ }^{1}$; Breno Souza SALGADO ${ }^{13}$; Carlos Humberto da Costa VIEIRA-FILHO ${ }^{4}$; Danielle Nascimento SILVA ${ }^{4}$; Emanoel Ferreira MARTINS-FILHO ${ }^{4}$; Stéfane Valgas TEIXEIRA ${ }^{1}$; Fernanda Camargo NUNES ${ }^{1,3}$; Karen Yumi Ribeiro NAKAGAKI ${ }^{1}$

\footnotetext{
${ }^{1}$ Universidade Federal de Minas Gerais, Instituto de Ciências Biológicas, Departamento de Patologia Geral, Laboratório de Patologia Comparada, Belo Horizonte - MG, Brazil

${ }^{2}$ Mayo Clinic, Division of Hematology and Oncology, Scottsdale - AZ, USA

${ }^{3}$ Secretaria da Agricultura, Pecuária e Irrigação, Instituto de Pesquisas Veterinárias Desidério Finamor, Departamento de Diagnóstico e Pesquisa Agropecuária, Eldorado do Sul - RS, Brazil

${ }^{4}$ Universidade Federal da Bahia, Escola de Medicina Veterinária, Departamento de Patologia e Clínica, Salvador - BA, Brazil ${ }^{5}$ Universidade Federal de Minas Gerais, Escola de Veterinária, Hospital Veterinário, Belo Horizonte - MG, Brazil

${ }^{6}$ Fundação Oswaldo Cruz, Centro de Pesquisas Gonçalo Moniz - BA, Brazil

${ }^{7}$ Universidade Estadual Paulista, Faculdade de Ciências Agrárias e Veterinárias, Departamento de Clínica e Cirurgia, Jaboticabal - SP, Brazil

${ }^{8}$ Universidade de São Paulo, Faculdade de Medicina Veterinária e Zootecnia, Departamento de Patologia, São Paulo - SP, Brazil

${ }^{9}$ Universidade Federal do Rio Grande do Sul, Faculdade de Veterinária, Departamento de Medicina Animal, Porto Alegre, RS - Brazil

${ }^{10}$ Onco Cane Clínica Veterinária, São Paulo - SP, Brazil

${ }^{11}$ Universidade Estadual de Londrina, Centro de Ciências Agrárias, Departamento de Medicina Veterinária Preventiva, Londrina - PR, Brazil

${ }^{12}$ Universidade Federal de Pelotas, Faculdade de Veterinária, Departamento de Patologia Animal, Laboratório Regional de Diagnóstico, Pelotas - RS, Brazil

${ }^{13}$ Universidade Federal do Espírito Santo, Centro Biomédico, Vitória - ES, Brazil
}

\begin{abstract}
Mammary neoplasms are described as the third most common type of feline tumor, after haematopoietic and skin tumors, and present a challenge for clinicians because the prognosis for feline mammary tumors ranges from guarded to poor. Thus, it is necessary to define new therapeutic approaches and establish more in-depth knowledge about this disease in felines. The main aspects of the diagnosis, prognosis and treatment of feline mammary neoplasia were discussed, aiming to standardize the criteria and to serve as a guide for pathologists and veterinary clinicians.
\end{abstract}

Keywords: Neoplasia. Feline. Pathology. Therapeutic.

\section{Resumo}

As neoplasias mamárias são descritas como o terceiro tipo mais frequente de tumor em felinos (após as neoplasias hematopoiéticas e cutâneas) e apresentam um desafio para os clínicos devido ao prognóstico, que varia de reservado a ruim. Assim, é necessário conhecer melhor essa doença em felinos e definir novas abordagens terapêuticas. Discutiuse os principais aspectos de diagnóstico, prognóstico e tratamento da neoplasia mamária felina, com o objetivo de padronizar os critérios e servir de guia para patologistas e clínicos veterinários.

Palavras-chave: Neoplasia. Felinos. Patologia. Terapêutica.

Correspondence to:

Geovanni Dantas Cassali

Universidade Federal de Minas Gerais, Instituto de Ciências

Biológicas, Departamento de Patologia Geral, Laboratório de

Patologia Comparada

Av. Antonio Carlos, 6627 - Pampulha

CEP 31270-901, Belo Horizonte, MG, Brazil

e-mail: cassalig@icb.ufmg.br

Received: $3 / 8 / 2017$

Approved: 28/2/2018

\section{Introduction}

During the $1^{\text {st }}$ and $2^{\text {nd }}$ Mammary Pathology Meeting in 2011 and 2013, which resulted in the Cassali et al. (2011) and Cassali et al. (2014) publications, respectively, several participants requested that the main aspects of feline mammary neoplasms should also be addressed. Due to some particularities of these tumors in the cat, a specific discussion was required. Thus, at the $3^{\text {rd }}$ 
Mammary Pathology Meeting, held on October 20-21, 2016 in Salvador, Brazil, the main aspects of the diagnosis, prognosis and treatment of feline mammary neoplasms were discussed, aiming to standardize the criteria and serve as a guide for pathologists and veterinary clinicians.

\section{Epidemiology and risk factors}

Mammary neoplasms are described as the third most common type of feline tumor, after haematopoietic and skin tumours (MACEWEN et al., 1984; MISDORP, 2002; OVERLEY et al., 2005; LANA et al., 2007). However, in a survey conducted in Brazil, mammary neoplasms represented the second most common type of tumor in the species (Togni et al., 2013). Its highest incidence is observed between 10 and 11 years of age (MISDORP, 2002) and in intact females (LANA et al., 2007). Intact cats have a seven-fold higher risk of developing mammary tumors when compared to spayed cats (WALDROW, 2001; OVERLEY et al., 2005; SORENMO, 2013).

In Brazil, a breed predisposition was not observed (CUNHA et al., 2016), as opposed to a previous international study that found Siamese cats to be more predisposed to mammary tumors (SORENMO et al., 2013). This fact is likely due to the domestic feline population in Brazil being predominantly composed of mongrel cats (CUNHA et al., 2016).

As has been observed in women and bitches, hormones also have a strong influence on mammary tumor development in cats. Early spaying, from six to 12 months, reduces the risk of mammary tumor formation in cats (RUTTEMAN et al., 2001; OVERLEY et al., 2005). The risk of mammary tumor development in cats spayed before six months of age is reduced by $91 \%$; in those spayed before one year of age, the risk is reduced up to $86 \%$; and, in contrast, the risk is only reduced by $11 \%$ when the animals are spayed between 13 and 24 months of age (OVERLEY et al., 2005; LANA et al., 2007).

\section{Clinical and pathological aspects}

At least $80 \%$ of feline mammary tumors are malignant (BOSTOCK, 1986; MISDORP et al., 1999). Many of these, especially large and invasive tumors, adhere to the skin and are ulcerated. In addition, lymph vessel and lymph node invasion are common. Regional and distant metastases can be observed in more than $80 \%$ of cats with malignant mammary tumors (LANA et al., 2007) and most often affect the lungs, although they can also be found in the pleura, liver, diaphragm, adrenal glands, spleen, kidneys, uterus and ovaries (WEIJER, 1972; HAYES, 1981; SORENMO, 2013). Multiple mammary gland involvement is frequent and can be observed and, just as in bitches, the abdominal mammary glands are the most affected (BORREGO, 2009; SORENMO, 2013; CAMPOS et al., 2014). The prognosis is guarded to poor, and the average survival time is less than one year (OVERLEY et al., 2005; LANA et al., 2007).

\section{Clinical staging}

Clinical staging in female mammary tumors has the objective of evaluating the size of the primary tumor, the involvement of the regional lymph nodes (axillary and inguinal) and the presence of distant metastasis, which allows establishing a prognosis and planning the treatment. Clinical staging should be performed according to the staging system of the World Health Organization (OWEN, 1980), modified for feline mammary tumors (Table 1; BORREGO et al., 2009; MCNEILL et al., 2009).

Table 1 - Clinical staging of the World Health Organization, modified for feline mammary tumors, according to the TNM system

\begin{tabular}{cccc}
\hline Stage & $\mathbf{T}$ & $\mathbf{N}$ & $\mathbf{M}$ \\
\hline II & $\mathrm{T}_{1}$ & $\mathrm{~N}_{0}$ & $\mathrm{M}_{0}$ \\
III & $\mathrm{T}_{2}$ & $\mathrm{~N}_{0}$ & $\mathrm{M}_{0}$ \\
& $\mathrm{~T}_{1-2}$ & $\mathrm{~N}_{1}$ & $\mathrm{M}_{0}$ \\
IV & $\mathrm{T}_{3}$ & $\mathrm{~N}_{0-1}$ & $\mathrm{M}_{0}$ \\
\hline
\end{tabular}

T: size of primary tumor; $\mathrm{N}$ : lymph node; $\mathrm{M}$ : metastasis; $\mathrm{T}_{1}$ : tumor size $<2 \mathrm{~cm}$; $\mathrm{T}_{2}$ : tumor size $2-3 \mathrm{~cm} ; \mathrm{T}_{3}$ : tumor size $>5 \mathrm{~cm} ; \mathrm{N}_{0}$ : no regional lymph node metastasis; $\mathrm{N}_{1}$ : ipsilateral lymph node involved

Source: Borrego et al. (2009); McNeill et al. (2009)

\section{Histological classification of tumors}

Approximately $80 \%$ of feline mammary tumors are malignant; however, benign lesions also occur. Hyperplasias and dysplasias, such as fibroepithelial hyperplasia, lobular hyperplasia and duct ectasia, are examples of benign nonneoplastic lesions (MISDORP, 1999).

Most of the malignant feline mammary tumors are classified as adenocarcinomas and are subdivided into histological types: tubulopapillary, solid, cribriform and in situ carcinoma. Other subtypes found includelipid-rich carcinoma (KAMSTOCK et al., 2005), squamous cell carcinoma, mucinous carcinoma, carcinosarcoma, adenosquamous carcinoma (GIMENEZ et al., 2010), micropapillary 
carcinoma, papillary carcinoma, tubular carcinoma, glycogen-rich carcinoma, malignant adenomyoepithelioma and carcinoma in mixed tumour (CAMPOS et al., 2014). Inflammatory carcinoma and lymphangiosarcoma have also been described (PEREZ-ALENZA, 2004; SUGIYAMA, 2007). Table 2 outlines the histological classification of mammary tumors in cats.

Table 2 - Histological classification of feline mammary tumors

Histological classification of feline mammary tumors

1. Malignant tumors

1.1 Non-infiltrating (in situ) carcinoma

1.2 Tubulopapillary carcinoma

1.3 Solid carcinowma

1.4 Cribriform carcinoma

1.5 Squamous cell carcinoma

1.6 Mucinous carcinoma

1.7 Carcinosarcoma

1.8 Carcinoma or Sarcoma in benign tumor

1.9 Micropapillary carcinoma

1.10 Lipid-rich carcinoma

2. Benign tumors

2.1 Adenoma

2.2 Fibroadenoma

2.3 Benign mixed tumor

2.4 Duct papilloma

3. Special types of malignant neoplasms

3.1 Tubular carcinoma

3.2 Papillary carcinoma

3.3 Glycogen-rich carcinoma

3.4 Carcinoma in mixed tumor

3.5 Malignant adenomyoepithelioma

4. Non-neoplastic benign lesions

4.1 Ductal hyperplasia

4.2 Lobular hyperplasia

4.3 Fibroadenomatous change (feline mammary hypertrophy, fibroepithelial hypertrophy), fibroepithelial hyperplasia

4.4 Adenosis

4.5 Duct ectasia

Source: Misdorp et al. (1999); Campos et al. (2015)

\section{Microscopic description of mammary lesions}

\section{Malignant tumors}

Carcinoma in situ: characterized by neoplastic epithelial cells that proliferate both into the lumen of the extralobular ducts and to the terminal duct-lobular units of the mammary gland without invasion or discontinuity of the basal membrane (Figure 1A). The neoplastic cells can be arranged in papillary patterns: micropapillary (Figure 1B), cribriform, solid or solid with comedonecrosis (central necrosis).

Tubulopapillary carcinoma: epithelial neoplasia characterized by tubular formations and/or papillary projections. This lesion type can be divided into tubular carcinoma and papillary carcinoma, depending on the arrangement found. It is important to differentiate them from the cribriform type, which is frequently diagnosed in this species (Figure 1C).

Cribriform carcinoma: malignant epithelial neoplasia characterized by the formation of secondary lumina, forming regular spaces with defined borders ("sieve-like" openings). Foci of central necrosis are frequently observed (Figure 1D). The coexistence of carcinomatous areas in situ with the same pattern is common, with variable mitotic indexes.

Solid carcinoma: microscopically, the epithelial cells have a solid arrangement, forming leaflets, cords or nests of cells with small or moderate amounts of surrounding stroma. The cells have a rounded shape, a high nucleus: cytoplasm ratio and clearly visible nucleoli. Some solid carcinomas may present cells with vacuolated cytoplasm, suggesting a possible myoepithelial origin (Figure 2A). Areas of necrosis and high mitotic indexes are common.

Micropapillary carcinoma: malignant proliferation characterized by epithelial cells arranged in a moruliform pattern within cystic spaces. In situ and invasive areas can be observed in the same tumor (Figure 2B). Usually associated with other histological types, such as tubulopapillary carcinomas. Lymphatic invasion and lymph node metastasis are often observed.

Carcinosarcoma: malignant tumors composed by a population of heterogeneous cells of epithelial and mesenchymal origin. Epithelial cells are arranged in solid nests, tubules and/or papillae and exhibit prominent ovoid nuclei and nucleoli. The mesenchymal proliferation is highly cellular, presenting pleomorphic cells in fusiform form and elongate to oval nuclei, with moderate to marked mitotic indexes. Areas with myxoid, chondroid and/or osteoid matrix formation may be observed, along with mature adipose and cartilaginous and/or bone tissue, possibly containing bone marrow. For poorly differentiated tumors, the use of an immunohistochemical technique with cytokeratin (CK) and vimentin is suggested (PANIAGO et al., 2010; CASSALI et al., 2014). 


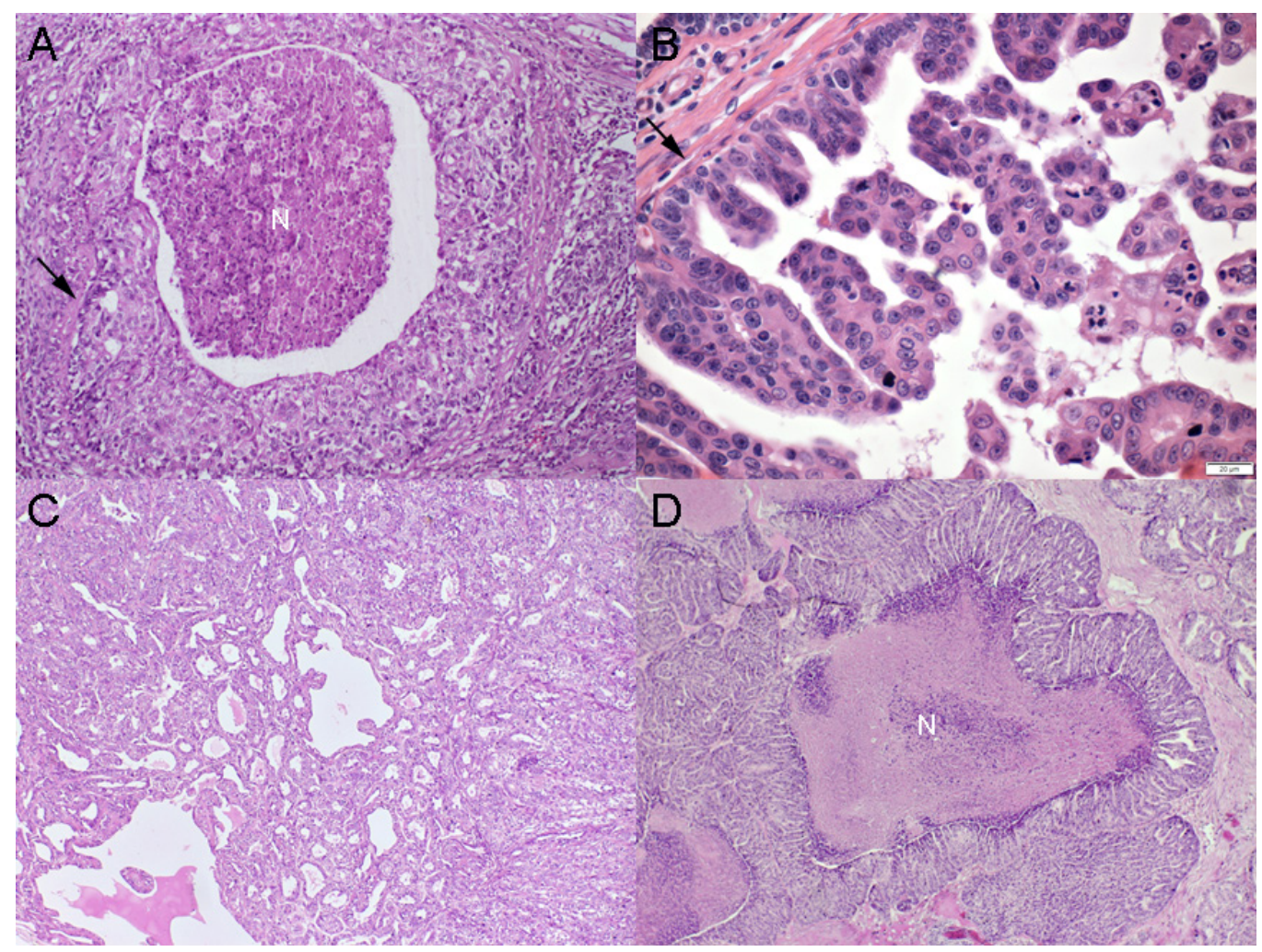

Figure $1-(\mathrm{A})$ and (B): Carcinoma in situ. Neoplastic epithelial cells that proliferate into the lumen without invasion or discontinuity of the basal membrane (arrow); (A): Comedocarcinoma with central area of necrosis (N). H\&E. 40x; (B): Micropapillary. Papillary projections without connective axis. H\&E. 40x; (C): Tubulopapillary carcinoma. Tubular formations and papillary projections H\&E. 10x; (D): Cribriform carcinoma. Formation of secondary lumina, forming regular spaces with defined borders associated with foci of central necrosis (N). H\&E. 10x

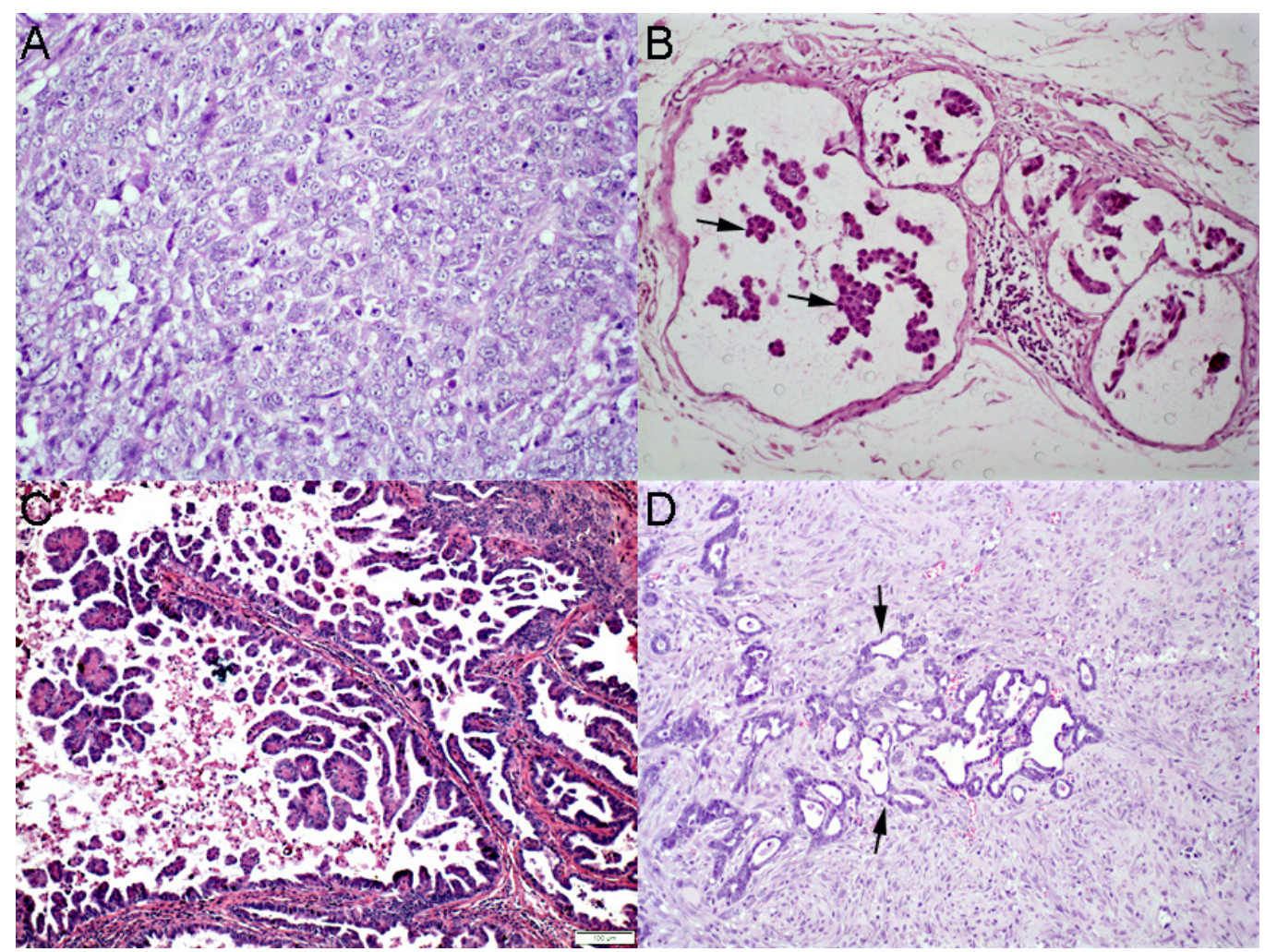

Figure 2 - (A); Solid carcinoma. Epithelial cells with a solid arrangement, forming nests of cells with small amount of surrounding stroma. H\&E. 40x; (B): Micropapillary carcinoma. Epithelial cells arranged in a moruliform (arrow) pattern within cystic spaces. H\&E. 20x; (C): Papillary carcinoma. Pedunculated arborescent branching composed of cubic to columnar cells overlying a delicate fibrovascular stromal axis. H\&E. 10x; (D). Tubular carcinoma. Small invasive tubular structures (arrow) associated with desmoplatic reaction. H\&E. 20x 
Malignant adenomyoepithelioma: tumor characterized by proliferation of myoepithelial cells that exhibit moderate pleomorphism, associated with in situ and invasive areas of malignant epithelial cells. Epithelial cells exhibit moderate pleomorphism and multiple and prominent nucleoli. In general, the cells of this tumor type have a low mitotic index.

Papillary carcinoma: papillary carcinomas in the cat are generally pure and characterized by sessile or pedunculated arborescent branching composed of cubic to columnar cells overlying a delicate fibrovascular stromal axis (Figure 2C). The frequencies of stromal invasion and lymphatic embolization are high, but the tumors may be intraductal. Eventually, these tumors become cystic and have been called papillary cystadenocarcinoma (HAMPE; MISDORP, 1974). In women, establishing the diagnosis of intraductal papillary carcinoma (ICC) requires that at least $90 \%$ of the papillae be devoid of myoepithelial cells, which can be verified with immunohistochemical evaluation and allows a safe distinction between ICC and ductal papillomas (TAVASSOLI; DEVILEE, 2004).

Tubular carcinoma: the typical characteristics of a pure tubular carcinoma, in which at least $90 \%$ of the tumor exhibits this histological pattern, are the presence of small tubular structures, oval to round, often angulated, covered by a single layer of small and regular cells with low nuclear pleomorphism and few mitotic figures, with incomplete or absent basal membrane and empty lumen (Figure 2D). This tumor is essentially invasive, with areas of necrosis and a moderate desmoplastic reaction being common. The concomitant occurrence with cribriform or micropapillary in situ foci is common in women (TAVASSOLI; DEVILEE, 2004).

Glycogen-rich carcinoma: microscopic evaluation demonstrates epithelial cells arranged in a predominantly solid pattern, tumor cells present an ample, granular, and foamy clear cytoplasm, and moderate cellular pleomorfism (Figure 3A). The presence of cytoplasmatic glycogen should be confirmed through diastase digestion followed by PAS staining.

Mucinous carcinoma: a rare tumor in cats characterized primarily by the abundant presence of intra- or extracellular mucin, in association with the proliferation of epithelial cells in solid, tubular or papillary arrays arranged in large compartments delimited by delicate fibrous septa. They can be pure, that is, $100 \%$ mucinous, or, more commonly, mixed, when other carcinomatous patterns are present. Mucin may form small or broad extracellular lakes, where it is amphiphilic to slightly basophilic, or may be found within the cell cytoplasm, where it stains slightly eosinophilic and results in signet ring cells. In most cases, the tumor is positive for Alcian blue at $\mathrm{pH} 2.5$, and less frequently, it is reactive to periodic acid-Schiff (PAS) with diastase, proving to be rich in acid mucopolysaccharides (SARLI et al., 2006).

Lipid-rich carcinoma: a rare tumor, one that has already been reported in cats, characterized by an expansive growth of tubulo-acinar structures delimited by dense fibrous septa, which were composed of cohesive clusters of round to polygonal cells. These cells had eosinophilic, foamy, moderate to wide cytoplasm with vacuoles of varying size, round and distinct, repelling the nucleus peripherally. The contents of these vacuoles are negative for PAS and Alcian blue and positive for oil-red (KAMSTOCK et al., 2005).

\section{Benign tumors}

Adenoma: benign tumor composed of acinar structures presenting a layer of epithelial and myoepithelial cells, surrounded by basal membrane. The cells are well differentiated and exhibit expansive and porous growth, with well-defined borders. Adenoma must be differentiated from adenosis because it exhibits loss of the architecture with absence of intralobular ducts. Some adenomas may exhibit intratubular secretion.

Fibroadenoma: relatively common benign neoplasia in cats. It is characterized by a proliferation of epithelial cells in a tubular array (see adenoma) enveloped abundantly by fibroblast stromal elements. Two subtypes are described: pericanalicular, when the epithelial cells are surrounded by the stroma, and the intracanalicular, when the epithelial cells are compressed and deformed by the stroma (Figure 3B). Mitoses are rare.

Benign mixed tumor: proliferation of benign epithelial cells in a single layer tubular and/or papillary arrangement associated with proliferation of myoepithelial cells with benign myxoid and/or chondroid matrix and/or bone matrix formation, along with mature cartilage and/or bone tissue. The architecture can sometimes be quite heterogeneous, and the cellular pleomorphism can be moderate, eventually leading to a malignant diagnosis by less-experienced pathologists. 


\section{Non-neoplastic benign lesions}

Ductal hyperplasia: characterized by the proliferation of well-differentiated epithelial cells, morphologically like the normal cells of the mammary ducts. The cells proliferate within the duct and are arranged in one or more layers, sometimes forming irregular intraductal bridges. A layer of myoepithelial cells is present delimiting the ducts. The lesion may be typical or atypical. Typical lesions present narrow bridges with elongated and twisted cells that create irregular peripheral fenestrations; cells and their nuclei differ in appearance and location. Atypical lesions produce regularly distributed monomorphic cells with round to ovoid nuclei and create more elaborate architectural patterns with more robust epithelial bridges. The distinction between atypical lesions and low-grade ductal carcinoma in situ may be difficult. When cytological and architectural features are present throughout the entirety of at least two units, the diagnosis of ductal carcinoma in situ is more appropriate.

Lobular hyperplasia: occurs in the terminal portions of the lobular units of the mammary glands, which are occupied by a uniform overgrowth of cells with low pleomorphism and uniform nuclei.
Fibroepithelial hyperplasia: non-neoplastic mammary proliferation induced by endogenous or synthetic progesterone. Microscopically, it is characterized by proliferation of ducts lined by one or more layers of epithelial cells, exhibiting low pleomorphism, surrounded by edematous and loose connective tissue. Mitotic figures are rare, but they can be visualized in both the stroma and the epithelium (Figure 3C). The presence of inflammatory infiltrate is infrequent. Fibroepithelial hyperplasia frequently affects all mammary glands, which are swollen, with areas of necrosis and secondary bacterial infection (HAYDEN et al., 1981).

Adenosis: characterized by the increased number of acini with or without dilation of the intralobular mammary ducts, maintaining the architecture, but with an increase in the diameter of the lobular units.

Duct ectasia: cystic dilation of the galactophore ducts. Microscopically, it is characterized by variable ductal dilation, surrounded by a dense fibrous stroma, frequently associated with mononuclear inflammatory infiltrate (Figure 3D). It can present proteinaceous and homogeneous secretion with the presence of foam cells.

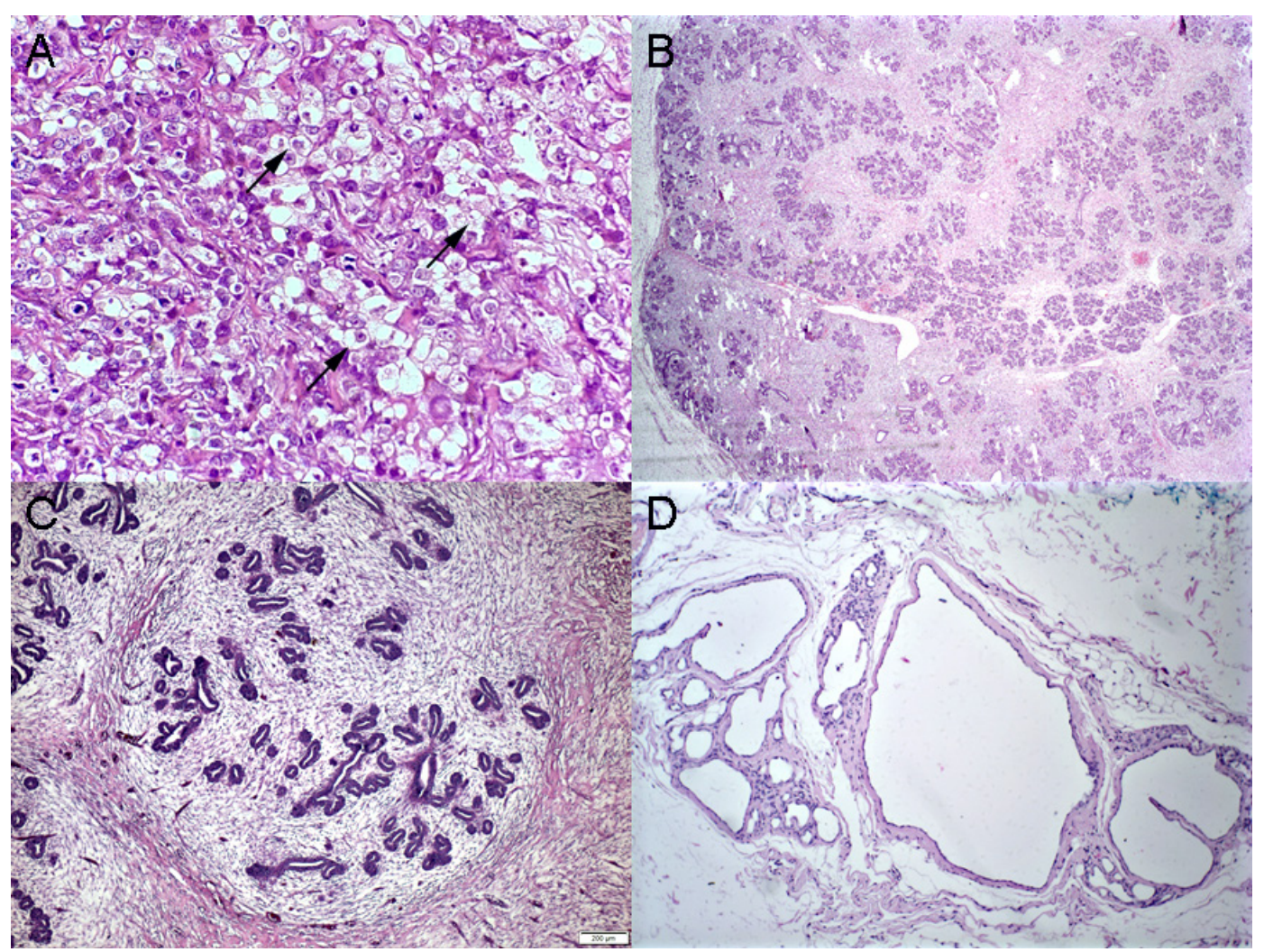

Figure 3 - (A): Glycogen rich carcinoma. Epithelial cells arranged in a predominantly solid pattern, tumor cells present an ample, granular, and foamy clear cytoplasm (arrow), and moderate cellular pleomorfism. H\&E. 40x; (B); Fibroadenoma. Epithelial cells in a tubular array enveloped abundantly by fibroblast stromal elements. H\&E. 2x; (C): Fibroepithelial hyperplasia. Proliferation of ducts lined by one or more layers of epithelial cells, surrounded by edematous and loose connective tissue. H\&E. 4x; (D): Duct ectasia. Variable ductal dilation, surrounded by a dense fibrous stroma. H\&E. 10x 


\section{Histological grading}

Like mammary carcinomas in bitches, histopathological grading of feline mammary tumors is of extreme importance (CAVALCANTI; CASSALI, 2006; MENDES et al., 2007; DUTRA et al., 2008; ESTRELA-LIMA et al., 2010). Histological grading is based on evaluations of tubular formation, nuclear pleomorphism and mitotic count (ELSTON; ELLIS, 1991). In veterinary medicine, there are some histological grading systems with specific criteria (GILBERTSON et al., 1983; LAGADIC; ESTRADA, 1990; ELSTON; ELLIS, 1991; MISDORP et al., 1999), and, due to the importance of histological grading as a prognostic factor and of the differences found between canine and feline mammary neoplasia, a species-specific system has been sought (MILLS et al., 2015). However, the method proposed by Elston and Ellis $(1991 ; 1998)$ (Table 3) is the most widely used and has been described as an independent prognostic factor in malignant mammary neoplasia in cats (SEIXAS et al., 2011; CAMPOS et al., 2015). Therefore, the authors believe this method should be preferred until clear evidence of improved prognostic stratification is demonstrated with novel methods.

Table 3 - Nottingham system

\begin{tabular}{ccc}
\hline Characteristics & Score \\
\hline Tubular formation & $>75 \%$ & 1 \\
& $10-75 \%$ & 2 \\
Nuclear pleomorphism & $<10 \%$ & 3 \\
& Mild & 1 \\
& Moderate & 2 \\
Mitotic count* & Marked & 3 \\
& $0-8$ & 1 \\
& $9-16$ & 2 \\
& $>17$ & 3 \\
\hline
\end{tabular}

\begin{tabular}{cc}
\hline Sum of scores & Degree \\
\hline $3-5$ & I \\
$6-7$ & II \\
$8-9$ & III \\
\hline
\end{tabular}

${ }^{*}$ Adapted according to the size of the field of microscopy used in this study $=$ $0.55 \mathrm{~mm}$

Source: Elston, Ellis $(1991,1998)$

\section{Prognostic factors}

Knowledge of the prognostic factors is extremely important in the determination of therapeutic programs for human breast cancer patients, with adequate and individualized intensity and effectiveness (ABREU;
KOIFMAN, 2002). Prognostic factors are clinical, pathological and biological characteristics of the individuals and their tumors that allow predictions of clinical evolution and patient survival (ALLRED et al., 1998).

Tumor size is considered an important prognostic factor in cats, with tumors larger than $3 \mathrm{~cm}$ interfering negatively in overall survival (OS) and disease-free survival (MACEWEN et al., 1984; FOX et al., 1995; MACY, 1997; VISTE et al., 2002; OVERLEY et al., 2005; LANA et al., 2007; BORREGO et al., 2009). Other factors include the extent of surgery, type and histological grade, mitotic index, clinical staging, molecular markers and regional and distant metastases (NOVOSAD et al., 2006; LANA et al., 2007; GIMENÉZ et al., 2010; HUGHES; DOBSON, 2012).

Clinical staging considers the evaluation of the primary tumor, regional lymph nodes and possible distant metastasis sites (LANA et al., 2007). Although Borrego et al. (2009) did not demonstrate the prognostic value of clinical staging, with no difference between medians of diseasefree survival and OS, Novosad et al. (2006) demonstrated significantly longer disease-free survival for animals classified as stage I and the authors believe clinical stage assessment is important for therapeutic planning.

Seixas et al. (2011) reported higher OS associated with diagnoses of tubulopapillary and complex carcinomas compared with solid and micropapillary carcinomas. Novosad et al. (2006) reported lower OS in anaplastic carcinomas and higher OS in papillary and tubular carcinomas. Further studies with long-term follow-up are necessary to confirm the prognostic value of histologic type in feline mammary neoplasms.

Histological grade, evaluated by the Nottingham system, proposed by Elston and Ellis (1991), has been described as a reliable and independent prognostic factor in malignant mammary neoplasia in cats (SEIXAS et al., 2011; CAMPOS et al., 2015). The prognostic value was demonstrated by lower OS associated with more undifferentiated tumors (MILLANTA et al., 2002a; SEIXAS et al., 2011; CAMPOS et al., 2015).

The immunohistochemical evaluation of the cell proliferation index through immunostaining with Ki-67 is an excellent marker to determine the growth fraction in a given cell population (MILLANTA et al., 2002a). Previous studies on mammary lesions in cats describe a progressive increase in proliferative index from normal mammary glands, non-neoplastic lesions, benign tumors, 
in situ carcinomas, invasive carcinomas and metastases (MILLANTA et al., 2002a; DIAS PEREIRA et al., 2004; CAMPOS et al., 2015). In a recent study, Soares et al. (2016a) demonstrated that the Ki-67 index can be used as a prognostic biomarker in feline mammary carcinomas, especially in those with values greater than $14 \%$, which correlate positively with low OS, larger tumor size, low differentiation, presence of necrosis and negative status for epidermal growth factor receptor 2 (ErbB-2; HER2 in humans) and oestrogen receptor (ER).

The role of ovarian hormones in feline mammary neoplasia was evidenced by Overley et al. (2005) and Hayden et al. (1989), who observed loss of protection against the disease with increased hormonal exposure, prevalence of intact cats with mammary tumors when compared with the spayed population and sporadic occurrence of mammary lesions concomitant with the use of progestins. Despite these findings, feline mammary tumors are considered models of hormone-independent breast cancer in women because most tumors are considered negative for ER and progesterone receptor (PR) (LAS MULAS et al., 2000, 2002; MILLANTA et al., 2005a; LANA et al., 2007). However, a recent study described the prevalence of positive tumors for ER and PR using the recommendations of the American Society of Clinical Oncology and the American College of Pathologists for hormone receptor positivity (CAMPOS et al., 2015). Millanta et al. (2006) found a similar result using a cut-off point for positivity to hormonal receptors above $5 \%$. No association was found between ER and PR expression and OS in feline mammary neoplasia (MILLANTA et al., 2005).

Ordás et al. (2007) reported an association between tumors with ErbB-2 overexpression and characteristics that are indicative of increased malignancy: larger size, high histological grade and absence of hormone receptors. In addition, the prognostic significance of ErbB-2 expression was demonstrated by Millanta et al. (2005b) and Campos et al. (2015), with lower OS associated with higher ErbB-2 scores.

Cyclooxygenase 2 (Cox-2) is a rapidly induced enzyme involved in the malignant transformation process and tumor progression by interfering with cell proliferation and adhesion, apoptosis, immunological surveillance and angiogenesis (WILLIAMS et al., 1999; MILLANTA et al., 2006). The increase in Cox-2 expression was associated with lower OS, as described by Millanta et al. (2006) and Campos et al. (2015).

\section{Classification of molecular subtypes}

As in humans, mammary tumors in dogs and cats have gained new classifications according to molecular and prognostic studies (SOARES et al., 2016b, 2016c). Molecular phenotype has become important in the definition of tumor subtypes, based on the expression of immunohistochemical markers, such as ER and PR, ErbB-2 overexpression, CK expression (CK 5/6, CK 14 and $C K$ 17) and the epidermal growth factor receptor (EGFR) (HEROLD; ANDERS, 2013). In recent years, these markers have also been used in the molecular phenotyping of mammary neoplasia in cats, but with some differences in markers, evaluation methods and classification systems among the different study groups (BRUNETTI et al., 2013; WIESE et al., 2013; SOARES et al., 2016b, 2016c).

Wiese et al. classified 24 mammary tumors in cats based on the expression of ER, PR, ErbB-2, CK 5/6 and EGFR markers. The tumors were classified as luminal A $(\mathrm{ER}+, \mathrm{PR}+/-$ and ErbB-2-) or luminal B (ER+, PR+/and ErbB-2+) and those with ErbB-2 overexpression (ER-, PR+/- and ErbB-2+) or basal-like expression (CK 5/6+ and/or EGFR+). In that study, 19 (79.2\%) basallike tumors were identified; however, these data were not correlated with pathanatomical and clinical factors. In that same year, Brunetti et al. (2013) performed the molecular phenotyping of 21 feline mammary tumors, considering the expression profiles of the markers ER, PR, ErbB-2, CK 5/6, CK 14 and p63. The authors did not identify luminal A (ER+ and/or PR+, ErbB-2- and indifferent CK 5/6 or CK 14 or p63) or normal-like (all negative markers) tumors but did report 11 (52.4\%) cases of subtype luminal B (ER+ and/or PR+, ErbB-2+ and CK 5/6 or CK 14 or p63 indifferent), eight (38.1\%) cases of ErbB-2 overexpression (ER-, PR-, ErbB-2+ and indifferent CK 5/6 or CK 14 or p63) and two (9.5\%) basallike cases (ER-, PR-, ErbB-2-, CK 5/6+ and/or CK 14+ and/or p63+). Likewise, the molecular subtypes were not correlated with the prognostic factors and clinical followup of the animals, but the authors reported a discrepancy in the molecular phenotype between the primary tumor and its respective metastasis in $43 \%$ of the cases. Using the same panel and classification system, except for CK 14 and p63, Muscatello et al. (2015) evaluated five feline tumors via the tissue microarray (TMA) method. The authors reported three cases of subtype luminal B and two cases of ErbB-2 overexpression but also did not correlate the findings with clinical and pathological data. 
In 2013, the St. Gallen International Expert Consensus panel proposed a different molecular classification for breast tumors in women, in which it established six biologically distinct subtypes of breast cancer: luminal A, luminal B/HER2-negative, luminal B/HER2-positive, HER2positive (non-luminal), basal-like triple-negative and normal-like triple-negative (GOLDHIRSCH et al., 2013). $\mathrm{Ki}-67$ expression has also been used as a prognostic and predictive factor in the response to breast cancer treatment (LUPORSI et al., 2012). Recently, this classification was used in the clinicopathological evaluation of 266 mammary tumors in 102 cats, according to the criteria described in table 4 (SOARES et al., 2016b; 2016c).

Regarding the positivity criteria established by Soares et al. (2016a, 2016b, 2016c), mammary tumors in cats were considered positive for ER and/or PR when there was positive staining in more than $1 \%$ of the neoplastic cells, according to the Allred Score (positive when $>2$ ). For ErbB-2, the tumor was considered positive when the neoplastic cells had +2 or +3 staining scores. A score of +2 was characterized by complete staining of the membrane, even if it was weak or not uniform, but with an obvious circumferential distribution in at least $10 \%$ of cells; and a score of +3 was characterized by intense and uniform staining in at least $10 \%$ of the tumor cells. For CK 5/6 and/or CK 14, the tumor was considered positive when there was cytoplasmic or membrane staining in at least $1 \%$ of the neoplastic cells. Regarding Ki-67, after counting the positive cells in 1000 cells, the tumor was considered to have high proliferation when it showed a proliferative index greater than $14 \%$.

In the study by Soares et al. (2016b), the most prevalent subtype was luminal B/ ErbB2-negative (29.4\%), followed by luminal B/ ErbB2-positive (19.6\%), triplenegative (16.7\%), luminal A (14.7\%), normal-like triplenegative (12.7\%) and ErbB2-positive (6.9\%). The authors demonstrated a positive correlation between the basal-like and normal-like triple-negative subtypes and larger tumor size and prevalence of necrotic areas, along with positive correlations between the luminal B/ErbB2-positive, basallike and normal-like triple-negative subtypes with less differentiated tumors. However, although the animals with the luminal A subtypes had longer OS and longer diseasefree time, unlike the animals with basal-like triple-negative subtypes, which exhibited the shortest times, there was no significant difference in this study.

Subsequently, Soares et al. (2016c) evaluated disease progression in 61 cats with metastasis. After multivariate analysis, it was determined that molecular classification is an independent prognostic factor for OS and that animals with ErbB-2-positive or basal-like triple-negative tumor subtypes have a higher chance of death relative to the other molecular subtypes. In addition, a high cell proliferation index (Ki-67 > 14\%), tumor size and ulceration were also confirmed to be prognostic predictors of OS. Finally, the authors demonstrated increases in cell proliferation, ErbB2 overexpression and CK 5/6 appearance in the metastases linked to their primary tumors, suggesting that the disease progresses to more aggressive molecular subtypes.

Currently, evaluating the status of ER and PR is one of the pillars of mammary cancer diagnosis. Compared with humans, cats appear to exhibit different trends in this status, and a high percentage of feline mammary tumors are negative for ER. Therefore, these observations suggest that these tumors may be appropriate models for advanced stages of ER-negative breast cancer in women (MILLANTA et al., 2005; ZAPPULLI et al., 2005). The investigation of potential new markers provides information relevant for clinical management and the understanding of neoplastic molecular pathogenesis and may have implications for the use of feline mammary tumors as spontaneous models for human disease (HUGHES; DOBSON, 2012).

Table 4 - Molecular classification of subtypes of feline mammary tumors

\begin{tabular}{|c|c|c|c|c|c|c|}
\hline & \multirow{2}{*}{ Luminal A } & \multicolumn{2}{|c|}{ Luminal B } & \multirow{2}{*}{ ErbB-2 positive } & \multicolumn{2}{|c|}{ Triple-Negative } \\
\hline & & ErbB-2 - & ErbB-2 + & & Basal-like & Normal-like \\
\hline ER & + and/or PR+ & + and/or PR+ & + and/or PR+ & - & - & - \\
\hline PR & + and/or ER+ & + and/or ER+ & + and/or ER+ & - & - & - \\
\hline ErbB-2 & - & - & + & + & - & - \\
\hline CK 5/6 & indifferent & indifferent & indifferent & indifferent & + & - \\
\hline Ki-67 & $<14 \%$ & $>14 \%$ & ns & ns & ns & ns \\
\hline
\end{tabular}

NS: not significant

Source: Soares et al. (2016b, 2016c) 


\section{Treatment}

\section{Fibroepithelial hyperplasia}

Treatment of fibroepithelial hyperplasia involves supportive care, including the use of analgesics, antibiotics, anti-inflammatories, diuretics, corticosteroids and warm compresses several times a day (OGILVIEG; MOORE, 2001). The PR antagonist, aglepristone, may be used at the dose of $10 \mathrm{mg} / \mathrm{kg}$ subcutaneously for four to five consecutive days (WEHREND et al., 2001) or $20 \mathrm{mg} / \mathrm{kg}$ once weekly (GORLINGER et al., 2002). Repeated treatments may be required for animals previously treated with exogenous progestogens for up to five weeks (JURKA; MAX, 2009). The definitive treatment consists of the removal of exogenous hormone exposure or oophorectomy (GIMENEZ et al., 2010). Fibroepithelial hyperplasia treatment should be performed only after the natural resolution of the disease, or with surgical access via the flank. As hyperplasia tends to decrease after hormonal stimulation, mastectomy is not indicated, solely reserved for cases of necrosis and extensive ulceration or when there is no response to clinical treatment (GIMENEZ et al., 2010). However, mammary involution may take from one to six months to fully occur (GORLINGER et al., 2002).

\section{Surgery}

Surgery is the main treatment recommended for feline mammary tumors (MISDORP, 2002) and can be performed in combination with other types of therapies, such as chemotherapy (LANA et al., 2007). Unilateral or bilateral radical mastectomy, regardless of tumor size and lesion location, is the surgical technique of choice and has been associated with a reduction of tumor recurrences, although it does not promote an increase in OS (MACEWEN et al., 1984; LANA et al., 2007; MCNEILL et al., 2009), which is the recommendation of the authors of the present paper. A previous study described significant OS differences associated with different surgical procedures, with higher OS in cats submitted to bilateral radical mastectomies (NOVOSAD et al., 2006).

\section{Sentinel lymph node}

The regional, axillary and inguinal, lymph nodes, even if not clinically altered, should be excised at the time of mastectomy due to the high incidence of regional metastases (CUNHA et al., 2016). For the axillary lymph node lymphadenectomy (Figure 4), Patent Blue dye (2.5\%) is applied intradermally at a dose of $2 \mathrm{mg} / \mathrm{kg}$, without exceeding the volume of $1 \mathrm{ml}$ per patient, to facilitate the identification and removal of the lymphatic tissue.

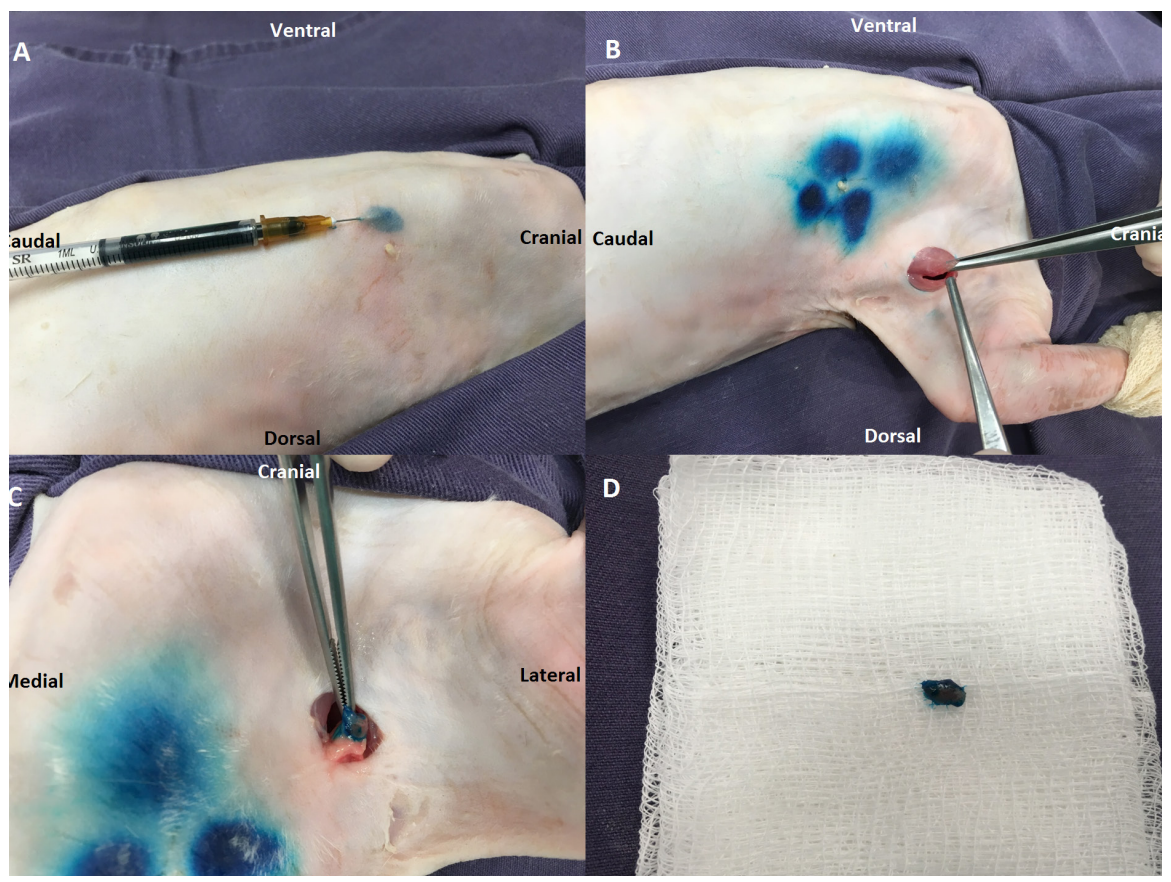

Figure 4 - Female cat patient placed in dorsal decubitus position for mastectomy. (A): Patent Blue intradermal application; (B): Twenty minutes after the intradermal application of the Patent Blue dye in 4 points distributed around the first mammary gland. Skin incision and divulsion of the subcutaneous and pectoral muscles in the middle third of the axillary region; (C): Identification of the axillary lymph node stained by patent blue; (D): Axillary lymph node of the patient after lymphadenectomy 


\section{Chemotherapy}

Several clinical, histopathological and immunohistochemical parameters can be evaluated to determine the need for antineoplastic chemotherapy treatment. As discussed during the $3^{\text {rd }}$ Mammary Pathology Meeting, current literature findings and the authors' experience indicate that adjuvant chemotherapy should be proposed for patients with malignant tumors larger than three centimetres in diameter, evidence of metastasis in regional or distant lymph nodes, and, after histopathological evaluation, invasion of neoplastic cells in lymphatic or blood vessels, histological grade III, and aggressive histological types, such as micropapillary carcinoma, solid carcinoma, cribriform carcinoma and carcinosarcoma. During the immunohistochemical examination, if the Ki-67 is greater than $14 \%$, the use of antineoplastic chemotherapy in the postoperative period is also indicated. Further studies should be performed to reevaluate the indications for chemotherapy as described.

However, the response to chemotherapy in animals diagnosed with metastases may not be satisfactory (GIMENÉZ et al., 2010). The chemotherapy protocols proposed by the literature consist of the use of doxorubicin as the only drug or in combination with cyclophosphamide, carboplatin as the only drug or in combination with doxorubicin and mitoxantrone as the only drug or in combination with cyclophosphamide (KITCHELL et al., 1999; LANA et al., 2007; CAMPOS et al., 2014; CUNHA et al., 2015). Additional clinical studies should be conducted to assess which doses and chemotherapeutic combinations are most effective in increasing the OS (GIMENÉZ et al., 2010).

Previous studies have evaluated the use of doxorubicin as adjuvant chemotherapy in malignant feline mammary neoplasia (NOVOSAD et al., 2006; MCNEILL et al., 2009) and the association of this chemotherapy drug with Cox2 inhibitors (BORREGO et al., 2009). Novosad et al. (2006) observed an increase in survival when surgery was associated with doxorubicin (median of 641 days after five cycles of chemotherapy), but the study did not include a control population. Borrego et al. (2009) also found a high median OS (460 days) when treating cats with malignant mammary neoplasia with surgery, doxorubicin and a non-selective Cox-2 inhibitor (meloxicam) at a dose of $0.2 \mathrm{mg} / \mathrm{kg} / \mathrm{SC} / \mathrm{SID}$, on the day of the surgical procedure, followed by $0.1 \mathrm{mg} / \mathrm{kg} / \mathrm{VO} / \mathrm{SID}$ for five days, followed by $0.025 \mathrm{mg} / \mathrm{kg} / \mathrm{VO} / \mathrm{SID}$ during antineoplastic chemotherapy treatment); however, this study did not include a control population. McNeill et al. (2009) did not observe a beneficial effect of the combination of chemotherapy with doxorubicin and surgery (median 848 days) when compared with cats treated with surgery alone (median 1,406 days). In addition, doxorubicin may be nephrotoxic in cats, therefore requiring careful evaluation of renal function (LANA et al., 2007). Another drug that can be used as a non-selective Cox-2 inhibitor is piroxicam at a dose of $0.3 \mathrm{mg} / \mathrm{kg}$ every 48 hours (BULMAN-FLEMING et al., 2010).

Carboplatin was proposed as a rescue therapy agent as either a single drug or in combination with other antineoplastic drugs (mitoxantrone and doxorubicin) for malignant feline mammary neoplasia with recurrence or metastases (NOVOSAD et al., 2006). Campos et al. (2014) did not observe a significant difference between cats diagnosed with malignant neoplasia of the mammary gland treated with surgery alone (median OS of 387 days) and treated with surgery and chemotherapy with carboplatin (median of OS of 428 days). However, the OSs described in that study were greater than the OS described in the literature (less than one year), demonstrating the efficiency of the surgical treatment. Literature findings regarding feline mammary neoplasms remain scarce and are generally composed of a small number of studied patients and, therefore, more research is needed.

\section{Follow-up}

After diagnosis of a malignant mammary tumor, it is essential to schedule routine re-evaluations of the feline patient for early disease detection. This reassessment includes haematological examinations (complete blood count and serum biochemical profile) to evaluate the patient's general condition and possible paraneoplastic syndromes, along with imaging tests (abdominal ultrasonography and thoracic radiographs) to assess evidence of asymptomatic metastases. The protocol indicated by the group is to perform re-evaluations every two months in the first six months after diagnosis and every three months between six and 24 months.

\section{Final considerations}

Feline mammary tumors present a challenge to the veterinarian clinician due to their guarded to poor prognosis. Thus, it is necessary to define new therapeutic approaches and to obtain more in-depth knowledge of the disease in this species. The available literature on feline mammary 
tumors can still be considered scarce. In addition, most of the studies found in the literature evaluate a small number of animals and are usually performed retrospectively and with methodologies that may be considered questionable. Therefore, even manuscripts with positive results may have an arguable validity. Papers that mainly evaluate pathological characteristics of mammary neoplasia in cats also usually present serious failures in methodology standardization. Therefore, different studies addressing the same topic cannot be added together since results vary greatly depending on the methodology employed. Furthermore, there is likely a reduced demand for veterinary care in veterinary reference

\section{References}

ABREU, E.; KOIFMAN, S. Fatores prognósticos no câncer da mama feminina. Revista Brasileira de Cancerologia, v. 48, n. 1, p. 113-131, 2002.

ALESKANDARANY, M.A.; RAKHA, E.A.; MACMILLAN, R. D.; POWE, D. G.; ELLIS, I. O.; GREEN, A. R. MIB1/Ki67 labelling index can classify grade 2 breast cancer into two clinically distinct subgroups. Breast Cancer Research and Treatment, v. 127, n. 3, p. 591-599, 2011. doi: 10.1007/ s10549-010-1028-3.

ALLRED, C. D.; HARVEY, J. M.; BERNARDO, M.; CLARK, G. M. Prognostic and predictive factors in breast cancer by immunohistochemical analysis. Modern Pathology, v. 11, n. 2, p. 155-168, 1998.

ALMEIDA, J. R. C. Classes de antineoplásicos. In: ALMEIDA, J. R. C. (Ed.). Farmacêuticos em oncologia: uma nova realidade. São Paulo: Atheneu, 2004. p. 105-110.

ARAÚJO, M. R.; DAMASCENO, K. A.; GAMBA, C. O.; CAMPOS, C. B.; CAMPOS, L. C.; REIS, D. C.; SOUZA, C. M.; CASSALI, G. D. Morphological and immunohistochemical characterization of five phyllodes mammary gland tumors in dogs. Online Journal of Veterinary Research, v. 18, n. 8, p. 688-695, 2014.

BORREGO, J. F.; CARTAGENA, J. C.; ENGEL, J. Treatment of feline mammary tumours using chemotherapy, surgery and a COX-2 inhibitor drug (meloxicam): a retrospective study of 23 cases (2002-2007). Veterinary and Comparative Oncology, v. 7, n. 4, p. 213-222, 2009. doi: 10.1111/j.1476-5829.2009.00194.x. centers by cat guardians. However, the reduced sample numbers of animals in each study can be circumvented with the collaboration of several institutions, thus generating larger multicentre studies. Several authors consider feline mammary tumors a model for the study of human neoplasia due to the similarities of several clinical and pathological features. We can then assume that the reverse path is also possible. Many methodologies in human medicine are well established after studies that demonstrate their effectiveness. The possibility of methodological standardization in veterinary medicine would allow a significant increase in the knowledge of the diseases that affect our patients.

BOSTOCK, D. E. Canine and feline mammary neoplasms. The British Veterinary Journal, v. 142, n. 6, p. 506-515, 1986. doi: 10.1016/0007-1935(86)90107-7.

BRUNETTI, B.; ASPRONI, P.; BEHA, G.; MUSCATELLO, L. V.; MILLANTA, F.; POLI, A.; BENAZZ, C.; SARLI, G. Molecular phenotype in mammary tumours of queens: correlation between primary tumour and lymph node metastasis. Journal of Comparative Pathology, v. 148, n. 2-3, p. 206-213, 2013. doi: 10.1016/j.jcpa.2012.05.012.

BULMAN-FLEMING, J.C.;TURNER, T.R.; ROSENBERG, M. P. Evaluation of adverse events in cats receiving longterm piroxicam therapy for various neoplasms. Journal of Feline Medicine and Surgery, v. 12, n. 4, p. 262-268, 2010. doi: 10.1016/j.jfms.2009.09.007.

CAMPOS, C. B.; DAMASCENO, K. A.; GAMBA, C. O.; RIBEIRO, A. M.; MACHADO, C. J.; LAVALLE, G. E.; CASSALI, G. D. Evaluation of prognostic factors and survival rates in malignant feline mammary gland neoplasms. Journal of Feline Medicine and Surgery, v. 18, n. 12, p. 1003-1012, 2015. doi: 10.1177/1098612X15610367.

CAMPOS, C. B.; GAMBA, C. O.; DAMASCENO, K. A.; LAVALLE, G. E.; CASSALI, G. D. Glycogen-rich clear cell carcinoma of the feline mammary gland: case report. Arquivo Brasileiro de Medicina Veterinária e Zootecnia, v. 68, n. 5, p. 1117-1120, 2016. doi: 10.1590/1678-4162-8797.

CAMPOS, C. B.; GAMBA, C. O.; DAMASCENO, K. A.; LAVALLE, G. E.; CASSALI, G. D. Malignant adenomyo- 
epithelioma in a feline mammary gland. Online Journal of Veterinary Research, v. 19, n. 3, p. 155-161, 2015.

CAMPOS, C. B.; NUNES, F. C.; LAVALlE, G. E.; CASSALI, G. D. Use of surgery and carboplatin in feline malignant mammary gland neoplasms with advanced clinical staging. In Vivo, v. 28, n. 5, p. 863-866, 2014.

CASSALI, G. D.; LAVALLE, G. E.; DE NARDI, A. B.; FERREIRA, E.; BERTAGNOLLI, A. C.; ESTRELA-LIMA, A.; ALESSI, A. C.; DALECK, C. R.; SALGADO, B. S.; FERNANDES, C. G.; SOBRAL, R. A.; AMORIM, R. L.; GAMBA, C. O.; DAMASCENO, K. A.; AULER, P. A.; MAGALHÃES, G. M.; ILVA, J. O.; RAPOSO, J. B.; FERREIRA, A. M. R.; OLIVEIRA, L. O.; MALM, C.; ZUCCARI, D. A. P. C.; TANAKA, N. M.; RIBEIRO, L. R.; CAMPOS, L. C.; SOUZA, C. C.; LEITE, J.; SOARES, L. M. C.; CAVAlCANTI, M. F.; FONTELES, Z. G. C.; SCHUCH, I. D.; PANIAGO, J.; OLIVEIRA, T. S.; TERRA, E. M.; CASTANHEIRA, T. L. L.; FELIX, A. O. C.; CARVAlHO, G. D.; GUIM, T. N.; GUIM, T. N.; GARRIDO, E.; FERNANDE, S. C.; MAIA, F. C. L.; DAGLI, M. L. Z.; ROCHA, N. S.; FUKUMASU, H.; GRANDI, F.; MACHADO, J. P.; SILVA, S. M. M. S.; BEZERRIL, J. E.; FREHSE, M. S.; ALMEIDA, E. C. P.; CAMPOS, C. B. Consensus for the diagnosis, prognosis and treatment of canine mammary tumors. Brazilian Journal of Veterinary Pathology, v. 4, n. 2, p. 153-180, 2011.

CASSALI, G. D.; LAVALLE, G. E.; FERREIRA, E.; ESTRELA-LIMA, A.; DE NARDI, A. B.; GHEVER, C.; SOBRAL, R. A.; AMORIM, R. L.; OLIVEIRA, L. O.; SUEIRO, F. A. R.; BESERRA, H. E. O.; BERTAGNOLLI, A. C.; GAMBA, C. O.; DAMASCENO, K. A.; CAMPOS, C. B.; ARAÚJO, M. R.; CAMPOS, L. C.; MONTEIRO, L. N.; NUNES, F. C.; HORTA, R. S.; REIS, D. C.; LUVIZOTTO, M. C. R.; MAGALHÃES, G. M.; RAPOSO, J. B.; FERREIRA, A. M. R.; TANAKA, N. M.; GRANDI, F.; UBUKATA, R.; BATSCHINSKI, K.; TERRA, E. M.; SALVADOR, R. A. C. L.; JARK, P. C.; DELECRODI, J. E. R.; NASCIMENTO, N. A.; SILVA, D.B.;SILVA,L.P.; FERREIRA, K.C.R.S.;FREHSE, M.S.; DI SANTIS, G. W.; SILVA, E. O.; GUIM, T. N.; KERR, B.; CINTRA, P. P.; SILVA, F. B. F.; LEITE, J. S.; MELLO, M. F. V.; FERREIRA, M. L. G.; FUKUMASU, H.; SALGADO, B. S.; TORRES, R. Consensus for the diagnosis, prognosis and treatment of canine mammary tumors: 2013. Brazilian Journal of Veterinary Pathology, v. 7, n. 2, p. 38-69, 2014.
CAVALCANTI, M.F.; CASSALI, G. D. Fatores prognósticos no diagnóstico clínico e histopatológico dos tumores de mama em cadelas: revisão. Clínica Veterinária, v. 11, n. 61, p. 56-64, 2006.

CUNHA, S. C.; CORGOZINHO, K. B.; SOUZA, H. J.; SILVA, K. V;; FERREIRA, A. M. Adjuvant chemotherapy with mitoxantrone for cats with mammary carcinomas treated with radical mastectomy. Journal of Feline Medicine and Surgery, v. 17, n. 12, p. 1000-1004, 2015. doi: 10.1177/1098612X14567159.

CUNHA, S.; CORGOZINHO, K.; JUSTEN, H.; SILVA, K.; LEITE, J.; FERREIRA, A. M. Survival and disease-free interval of cats with mammary carcinoma treated with chain mastectomy. Acta Scientiae Veterinariae, v. 44, n. 1, p. 1349, 2016. doi: 10.22456/1679-9216.80900.

DIAS PEREIRA, P.; CARVALHEIRA, J.; GÄRTNER, F. Cell proliferation in feline normal, hyperplastic and neoplastic mammary tissue: an immunohistochemical study. The Veterinary Journal, v. 168, n. 2, p. 180-185, 2004. doi: 10.1016/j.tvjl.2003.10.018.

DUTRA, A. P.; AZEVEDO JÚNIOR, G. M.; SCHMITT, F. C.; CASSALI, G. D. Assessment of cell proliferation and prognosticfactorsin canine mammarygland tumors. Arquivo Brasileiro de Medicina Veterinária e Zootecnia, v. 60, n. 6, p. 1403-1412, 2008. doi: 10.1590/S0102-09352008000600015.

ELLIS, I. O.; GALEA, M.; BROUGHTON, N.; LOCKER, A.; BLAMEY, R. W.; ELSTON, C. W. Pathological prognostic factors in breast cancer: II. Histological type: relationship with survival in a large study with long-term follow-up. Histopathology, v. 20, n. 6, p. 479-489, 1992. doi: 10.1111/ j.1365-2559.1992.tb01032.x.

ELSTON, C. W.; ELLIS, I. O. Assessment of histological grade. In: ELSTON, C. W.; ELLIS, I. O. (Eds.). Systemic pathology: the breast. 3. ed. Edinburgh: Churchill Livingstone, 1998. p. 365-384.

ELSTON, C. W.; ELLIS, I. O. Pathological prognostic factors in breast cancer: I. The value of histological grade in breast cancer: experience from a large study with longterm follow-up. Histopathology, v. 19, n. 5, p. 403-410, 1991. doi: 10.1111/j.1365-2559.1991.tb00229.x. 
ESTRELA-LIMA, A.; ARAÚJO, M. S.; COSTA-NETO, J. M.; TEIXEIRA-CARVALHO, A.; BARROUIN-MELO, S. M.; CARDOSO, S. V.; MARTINS-FILHO, O. A.; SERAKIDES, R.; CASSALI, G. D. Immunophenotypic features of tumor infiltrating lymphocytes from mammary carcinomas in female dogs associated with prognostic factors and survival rates. BMC Cancer, v. 10, p. 256, 2010. doi: 10.1186/1471-2407-10-256.

FISHER, B.; BRYANT, J.; WOLMARK, N.; MAMOUNAS, E.; BROWN, A.; FISHER, E. R.; WICKERHAM, D. L.; BEGOVIC, M.; DECILlIS, A.; ROBIDOUX, A.; MARGOLESE, R. G.; CRUZ JÚNIOR, A. B.; HOEHN, J. L.; LEES, A. W.; DIMITROV, N. V.; BEAR, H. D. Effect of preoperative chemotherapy on the outcome of women with operable breast cancer. Journal of Clinical Oncology, v. 16, n. 8, p. 2672-2685, 1998. doi: 10.1200/ JCO.1998.16.8.2672.

FOX, L. E.; MACEWEN, E. G.; KURZMAN, R. D.; DUBIELZIG, R. R.; HELFAND, S. C.; VAIL, D. M.; KISSEBERTH, W.; LONDON, C.; MADEWELL, B. R.; RODRIGUEZ JÚNIOR, C. O.; JEGLUM, K. A.; ROSEnberG, M.; ROSENTHAL, R. C. Liposome-encapsulated muramyl tripeptide phosphatidylethanolamine for the treatment of feline mammary adenocarcinoma: a multicenter randomized double-blind study. Cancer Biotherapy, v. 10, n. 2, p. 125 130, 1995. doi: 10.1089/cbr.1995.10.125.

GILBERTSON, S. R.; KURZMAN, I. D.; ZACHRAU, R. E.; HURVITZ, A. I.; BLACK, M. M. Canine mammary epithelial neoplasms: biologic implications of morphologic characteristics assessed in 232 dogs. Veterinary Pathology, v. 20, n. 2, p. 127-142, 1983. doi: $10.1177 / 030098588302000201$.

GIMENEZ, F.; HECHT, S.; CRAIG, L. E.; LEGENDRE, A. M. Early detection, aggressive therapy: optimizing the management of feline mammary masses. Journal of Feline Medicine and Surgery, v. 12, n. 3, p. 214-224, 2010. doi: 10.1016/j.jfms.2010.01.004.

GOLDHIRSCH, A.; WINER, E. P.; COATES, A. S.; GELBER, R. D.; PICCART-GEBHART, M.; THÜRLIMANN, B.; SENN, H. J. Personalizing the treatment of women with early breast cancer: highlights of the St Gallen international expert consensus on the primary therapy of early breast cancer 2013. Annals of Oncology, v. 24, n. 9, p. 2206-2223, 2013. doi: 10.1093/ annonc/mdt303.

GORLINGER, S.; KOOISTRA, H. S.; van den BROEK, A.; OKKENS, A. C. Treatment of fibroadenomatous hyperplasia in cats with aglepristone. Journal of Veterinary Internal Medicine, v. 16, n. 6, p. 710-713, 2002. doi: 10.1111/j.1939-1676.2002.tb02412.x.

HAMPE, J. F.; MISDORP, W. Tumours and dysplasias of the mammary gland. Bulletin of the World Health Organization, v. 50, n. 1-2, p. 111-133, 1974.

HAYDEN, D. W.; BARNES, D. M.; JOHNSON, K. H. Morphologic changes in the mammary gland of megestrol acetate-treated and untreated cats: a retrospective study. Veterinary Pathology, v. 26, n. 2, p. 104-113, 1989. doi: 10.1177/030098588902600202.

HAYDEN, D. W.; JOHNSTON, S. D.; KIANG, D. T.; JOHNSON, K.; BARNES, D. M. Feline mammary hypertrophy/fibroadenoma complex: clinical and hormonal aspects. American Journal of Veterinary Research, v. 42, n. 10, p. 1699-1703, 1981.

HAYES JÚNIOR, H. M.; MILNE, K. L.; MANDELL, C. P. Epidemiological features of feline mammary carcinoma. The Veterinary Record, v. 108, n. 5, p. 476-479, 1981. doi: $10.1136 /$ vr.108.22.476.

HEROLD, C. I.; ANDERS, C. K. New targets for triplenegative breast cancer. Oncology, v. 27, n. 9, p. 846-854, 2013.

HUGHES, K.; DOBSON, J. M. Prognostic histopathological and molecular markers in feline mammary neoplasia. Veterinary Journal, v. 194, n. 1, p. 19-26, 2012. doi: 10.1016/j.tvjl.2012.05.008.

JACOBS, T. M.; HOPPE, B. R.; POEHLMANN, C. E.; FERRACONE, J. D.; SORENMO, K. U. Mammary adenocarcinomas in three male cats exposed to medroxyprogesterone acetate (1990-2006). Journal of Feline Medicine and Surgery, v. 12, n. 2, p. 169-174, 2010. doi: 10.1016/j.jfms.2009.08.004. 
JURKA, P.; MAX, A. Treatment of fibroadenomatosis in 14 cats with aglepristone changes in blood parameters and follow-up. The Veterinary Record, v. 165, n. 22, p. 657-660, 2009. doi: 10.1136/vr.165.22.657.

KAMSTOCK, D. A.; FREDRICKSON, R.; EHRHART, E. J. Lipid-rich carcinoma of the mammary gland in a cat. Veterinary Pathology, v. 42, n. 3. p. 360-362, 2005. doi: 10.1354/vp.42-3-360.

KITCHELL, B.; LARUE, S. M.; ROOKS, R. L. Mammary tumors (dogs and cats). Veterinary cancer therapy handbook: chemotherapy, radiation therapy, and surgical oncology for the practicing veterinarian. 2. ed. Lakewood: AAHA, 1999. p. 61-64.

LAGADIC, M.; ESTRADA, M. Tumeurs de la mamelle. Encyclopédie Vétérinaire, v. 25, p. 1-9, 2000.

LANA, S. E.; RUTTEMAN, G. R.; WITHROW, S. J. Tumors of the mamary gland. In: WITHROW, S. J.; VAIL, D. M. (Eds.). Withrow \& MacEwen's small animal clinical oncology. 4. ed. Philadelphia: W. B. Saunders, 2007. p. 619-636.

MULAS, J. M.; van NIEL, M. V.; MILLÁN, Y.; BLANKENSTEIN, M. A.; MIL, F. V.; MISDORP, W. Immunohistochemical analysis of estrogen receptors in feline mammary gland benign and malignant lesions: comparison with biochemical assay. Domestic Animal Endocrinology, v. 18, n. 1, p. 111-125, 2000. doi: 10.1016/ S0739-7240(99)00067-3.

MULAS, J. M.; van NIEL, M. V.; MILLÁN, Y.; ORDÁS, J.; BLANKENSTEIN, M. A.; MIL, F. V.; MISDORP, W. Progesterone receptors in normal, dysplastic and tumourous feline mammary glands: comparison with oestrogen receptors status. Research in Veterinary Science, v. 72, n. 2, p. 153-161, 2002. doi: 10.1053/rvsc.2001.0542.

LAVAllE, G. E.; CAMPOS, C. B.; BERTAGNOLLI, A. C.; CASSALI, G. D. Canine malignant mammary gland neoplasms with advanced clinical staging treated with carboplatin and cyclooxygenase inhibitors. In Vivo, v. 26, n. 3, p. 375-379, 2012.

LUPORSI, E.; ANDRÉ, F.; SPYRATOS, F.; MARTIN, P. M.; JACQUEMIER, J.; PENAULT-LLORCA, F.;
TUBIANA-MATHIEU, N.; SIGAL-ZAFRANI, B.; ARNOULD, L.; GOMPEL, A.; EGELE, C.; POULET, B.; ClOUGH, K. B.; CROUET, H.; FOURQUET, A.; LEFRANC, J. P.; MATHELIN, C.; ROUYER, N.; SERIN, D.; SPIELMANN, M.; HAUGH, M.; CHENARD, M. P.; BRAIN, E.; CREMOUX, P.; BELLOCQ, J. P. Ki-67: level of evidence and methodological considerations for its role in the clinical management of breast cancer: analytical and critical review. Breast Cancer Research and Treatment, v. 134, n. 3, p. 895-915, 2007. doi: 10.1007/s10549-011-1837-z.

MACEWEN, E. G.; HAYES, A. A.; HARVEY,H.J.; PATNAIK, A. K.; MOONEY, S.; PASSE, S. Prognostic factors for feline mammary tumours. Journal of American Veterinary Medical Association, v. 185, n. 2, p. 201-204, 1984.

MACY, D. W. Feline oncology. The Veterinary Quarterly, v. 19, n. 1, p. 11-13, 1997. doi: 10.1080/01652176.1997.9694780.

MCNEILL, C. J.; SORENMO, K. U.; SHOFER, F. S.; GIBEON, L.; DURHAM, A. C.; BARBER, L. G.; BAEZ, J. L.; OVERLEY, B. Evaluation of adjuvant doxorubicinbased chemotherapy for the treatment of feline mammary carcinoma. Journal of Veterinary Internal Medicine, v. 23, n. 1, p. 123-129, 2009. doi: 10.1111/j.1939-1676.2008.0244.x.

MENDES, T. C.; GUIM, T. N.; DIAS, M. F.; BONELRAPOSO, J.; FERNANDES, C. G. Comparação entre os sistemas histomorfológico e de graduação histológica para classificação prognóstica de tumores mamários em cadelas. Acta Scientiae Veterinariae, v. 35, n. 3, p. 339-345, 2007.

MILLANTA, F.; CALANDRELLA, M.; BARI, G.; NICCOLINI, M.; VANNOZZI, I.; POLI, A. Comparison of steroid receptor expression in normal, dysplastic, and neoplastic canine and feline mammary tissues. Research in Veterinary Science, v. 79, n. 3, p. 225-232, 2005a. doi: 10.1016/j.rvsc.2005.02.002.

MILLANTA, F.; CALANDRELLA, M.; CITI, S.; DELLA SANTA, D.; POLI, A. Overexpression of HER-2 in feline invasive mammary carcinomas: an immunohistochemical survey and evaluation of its prognostic potential. Veterinary Pathology, v. 42, n. 1, p. 30-34, 2005b. doi: 10.1354/vp.42-1-30.

MILLANTA, F.; CITI, S.; DELLA SANTA, D.; PORCIANI, M.; POLI, A. Cox-2 expression in canine and feline 
invasive mammary carcinomas: correlation with clinicopathological features and prognostic molecular markers. Breast Cancer Research and Treatment, v. 98, n. 1, p. 115-120, 2006. doi: 10.1007/s10549-005-9138-z.

MILLANTA, F.; LAZZERI, G.; MAZZEI, M.; VANNOZZI, I.; POLI, A. MIB-1 labeling index in feline dysplastic and neoplastic mammary lesions and its relationship with postsurgical prognosis. Veterinary Pathology, v. 39, n. 1, p. 120-126, 2002a. doi: 10.1354/vp.39-1-120.

MILLS, S. W.; MUSIL, K. M.; DAVIES, J. L.; HENDRICK, S.; DUNCAN, C.; JACKSON, M. L.; KIDNEY, B.; PHILIBERT, H.; WOBESER, B. K.; SIMKO, E. Prognostic value of histologic grading for feline mammary carcinoma: a retrospective survival analysis. Veterinary Pathology, v. 52, n. 2, p. 238-249, 2015. doi: 10.1177/0300985814543198.

MISDORP, W. Tumors of the mammary gland. In: MEUTEN D. J. (Ed.). Tumors in domestic animals. Ames: Blackwell, 2002. p. 575-606.

MISDORP, W.; ELSE, R. W.; HELLMÉN, E.; LIPSCOMB, T. P. Histological classification of mammary tumors of the dog and the cat. 2. ed. Washington, DC: Armed Forces Institute of Pathology, 1999. 59 p.

NOVOSAD, C. A.; BERGMAN, P. J.; O'BRIEN, M. G.; MCKNIGHT, J. A.; CHARNEY, S. C.; SELTING, K. A.; GRAHAM, J. C.; CORREA, S. S.; ROSENBERG, M. P.; GIEGER, T. L. Retrospective evaluation of adjunctive doxorubicin for the treatment of feline mammary gland adenocarcinoma: 67 cases. Journal of the American Animal Hospital Association, v. 42, n. 2, p. 110-120, 2006. doi: 10.5326/0420110.

OGILVIEG, K.; MOORE, A. S. Feline oncology: a comprehensive guide to compassionate care. New Jersey: Veterinary Learning Systems, 2001. p. 503.

ORDÁS, J.; MILLÁN, Y.; DIOS, R.; REYMUNDO, C.; LAS MULAS, J. M. Proto-oncogene HER-2 in normal, dysplastic and tumorous feline mammary glands: an immunohistochemical and chromogenic in situ hybridization study. BMC Cancer, v. 7, p. 179-184, 2007. doi: 10.1186/1471-2407-7-179.
OVERLEY, B.; SHOFER, F. S.; GOLDSCHMIDT, M. H.; SHERER, D.; SORENMO, K. U. Association between ovariohysterectomy and feline mammary carcinoma. Journal of Veterinary Internal Medicine, v. 19, n. 4, p. 560-563, 2005. doi: 10.1111/j.1939-1676.2005.tb02727.x.

OWEN, L. N. TNM Classification of tumors in domestic animals. Geneva: World Health Organization, 1980.

PANIAGO, J. D. G.; VIEIRA, A. L. S.; OCARINO, N. M.; FRANÇA, S. A.; MALM, C.; CASSALI, G. D.; SERAKIDES, R. Mammary carcinosarcoma in cat: a case report. Arquivo Brasileiro de Medicina Veterinária e Zootecnia, v. 62, n. 4, p. 812-815, 2010. doi: 10.1590/S010209352010000400008.

PEREZ-ALENZA, M.D.; JIMENEZ, A.;NIETO, A.I.;PEÑA, L. First description of feline inflammatory mammary carcinoma: clinicopathological and immunohistochemical characteristics of three cases. Breast Cancer Research, v.6, n. 4, p. 300-307, 2004. doi: 10.1186/bcr790.

RASTOGI, P.; ANDERSON, S. J.; BEAR, H. D.; GEYER, C. E.; KAHLENBERG, M. S.; ROBIDOUX, A.; MARGOLESE, R. G.; HOEHN, J. L.; VOGEL, V. G.; DAKHIL, S. R.; TAMKUS, D.; KING, K. M.; PAJON, E. R.; WRIGHT, M. J.; ROBERT, J.; PAIK, S.; MAMOUNAS, E. P.; WOLMARK. N. Preoperative chemotherapy: updates of National Surgical Adjuvant Breast and Bowel Project Protocols B-18 and B-27. Journal of the Clinical Oncology, v. 10, n. 5, p. 778-785, 2008. doi: 10.1200/JCO.2007.15.0235.

RUTTEMAN, G. R.; WITHROW, S. J.; MACEWEN, E. G. Tumors of the mammary gland. In: WITHROW, S. J.; MACEWEN, E. G. (Eds.). Small Animal Clinical Oncology. 3. ed. Philadelphia: W. B. Saunders, 2001. p. 455-477.

SARLI, G.; BRUNETTI, B.; BENAZZI, C. Mammary mucinous carcinoma in the cat. Veterinary Pathology, v. 43, n. 5, p. 667-673, 2006. doi: 10.1354/vp.43-5-667.

SEIXAS, F.; PALMEIRA, C.; PIRES, M. A.; BENTO, M. J.; LOPES, C. Grade is an independent prognostic factor for feline mammary carcinomas: a clinicopathological and survival analysis. Veterinary Journal, v. 187, n. 1, p. 65-71, 2011. doi: 10.1016/j.tvjl.2009.10.030. 
SOARES, M.; CORREIA, J.; PELETEIRO, M. C.; FERREIRA, F. St Gallen molecular subtypes in feline mammary carcinoma and paired metastases-disease progression and clinical implications from a 3-year followup study. Tumour Biology, v. 37, n. 3, p. 4053-4064, 2016 c. doi: 10.1007/s13277-015-4251-z.

SOARES, M.; MADEIRA, S.; CORREIA, J.; PELETEIRO, M.; CARDOSO, F.; FERREIRA, F. Molecular based subtyping of feline mammary carcinomas and clinicopathological characterization. The Breast, v. 27, p. 44-51, 2016b. doi: 10.1016/j.breast.2016.02.016.

SOARES, M.; RIBEIRO, R.; CARVALHO, S.; PELETEIRO, M.; CORREIA, J.; FERREIRA, F. Ki-67 as a prognostic factor in feline mammary carcinoma: what is the optimal cutoff value? Veterinary Pathology, v. 53, n. 1, p. 37-43, 2016. doi: 10.1177/0300985815588606.

SORENMO, K. U.; WORLEY, D. R.; GOLDSCHMIDT, M. $\mathrm{H}$. Tumors of the mammary gland. In: WITHROW, S. J.; VAIL, D. M.; PAGE, R. L. (Eds.). Withrow and Macewen's small animal clinical oncology. 5. ed. St. Louis: Saunders Elsevier, 2013. p. 538-556.

SUGIYAMA, A.; TAKEUCHI, T.; MORITA, T.; OKAMURA, Y.; MINAMI, S.; TSUKA, T.; TABUCHI, T.; OKAMOTO, Y. Lymphangiosarcoma in a cat. Journal of Comparative Pathology, v. 137, n. 2-3, p. 174-78, 2007. doi: 10.1016/j.jcpa.2007.06.004.

TAVASSOLI, F. A.; DEVILEE, P. Pathology and genetics of tumours of the breast and female genital organs. Lyon: IARC, 2004. 432 p.

TESHOME, M.; HUNT, K. K. Neoadjuvant therapy in the treatment of breast cancer. Surgical Oncology Clinics of North America, v. 23, n. 3, p. 505-523, 2014. doi: 10.1016/j. soc.2014.03.006.

TOGNI, M.; MASUDA, E. K.; KOMMERS, G. D.; FIGHERA, R. A.; IRIGOYEN, L. F. Estudo retrospectivo de 207 casos de tumores mamários em gatas. Pesquisa Veterinária Brasileira, v. 33, n. 3, p. 353-358, 2013. doi: 10.1590/S0100-736X2013000300013.
TSAI, H.; YANG, I.; LIN, C.; CHAI, C.; HUANG, Y.; CHEN, C.; HOU, M.; KUO, C.; JUO, S.; WANG, J. Predictive value of vascular endothelial growth factor overexpression in early relapse of colorectal cancer patients after curative resection. International Journal of Colorectal Disease, v. 28, n. 3, p. 415-424, 2012. doi: 10.1007/s00384-012-1570-Z.

VISTE, J. R.; MYERS, S. L.; SINGH, B.; SIMKO, E. Feline mammary adenocarcinoma: tumor size as a prognostic indicator. The Canadian Veterinary Journal, v. 43, n. 1, p. 33-37, 2002.

WALDROW, D. R. Diagnosis and surgical management of mammary neoplasia in dogs and cats. Veterinary Medicine, v. 96, n. 12, p. 943-948, 2001.

WEHREND, A.; HOSPES, R.; GRUBER, A. D. Treatment of feline mammary fibroadenomatous hyperplasia with a progesterone- antagonist. The Veterinary Record, v. 148, n. 11, p. 346-347, 2001. doi: 10.1136/vr.148.11.346.

WEIJER, K.; HEAD, K. L.; MISDORP, W.; HAMPE, F. Feline malignant mammary tumors: morphology and biology: some comparisons with human and canine mammary carcinomas. Journal of the National cancer Institute, v. 49, n. 6, p. 1697-1704, 1972. doi: 10.1093/ jnci/49.6.1697.

WIESE, D. A.; THAIWONG, T.; YUZBASIYANGURKAN, V.; KIUPEL, M. Feline mammary basal-like adenocarcinomas: a potential model for human triplenegative breast cancer (TNBC) with basallike subtype. BMC Cancer, v. 13, p. 403, 2013. doi: 10.1186/1471-240713-403.

WILliAMS, C. S.; MANN, M.; DUBOIS, R. N. The role of cyclooxygenases in inflammation, cancer, and development. Oncogene, v. 18, n. 55, p. 7908-7916, 1999. doi: 10.1038/sj.onc.1203286.

ZAPPULLI, V.; RASOTTO, R.; CALIARI, D.; MAINENTI, M.; PEÑA, L.; GOLDSCHMIDT, M. H.; KIUPEL, M. Prognostic evaluation of feline mammary carcinomas a review of the literature. Veterinary Pathology, v. 52, n. 1, p. 46-60, 2015. doi: 10.1177/0300985814528221. 